\title{
Mesodermal Dysmorphogenesis of Ginsenosides: An Experimental Study
}

Uzma Daud, Qasim Muneer, Javeria Noor, Fahad Raza, Sarah Khalid

Department of Anatomy, Shalamar Medical \& Dental College, Lahore.

\begin{abstract}
Background: The versatile and dynamic activities of Panax Ginseng are attributed to its active components. They are readily available over the counter and are known for their effects as an aphrodisiac \& health building; in addition, they are given rather generously during pregnancy, as they are considered virtuous for the baby and mother. Despite its easy availability and excess usage, little is known about its effects on the fetus. The current experimental design was focused towards the lack of differentiation and inhibition of cell growth of mesodermal derivatives inflicted by PanaxGingex.

Methods:18 pregnant albino dams were randomly divided into three groups; Group A was control, Group B was Low dose and Group C was labelled as High dose groups. Tissues (bone, kidney and blood) were selected as derivatives of paraxial, intermediate and lateral plate mesoderm respectively and were used for light microscopic study.

Results and Conclusion: The light microscopic examination demonstrated extensive apoptosis and an escalation of angiogenesis. Both the histological findings were not only statistically significant but was clearly indicative of dysmorphogenesis. The results of present study raise a finger towards the un-supervised practice of over the counter preparations especially during the vital antenatal period of development.
\end{abstract}

Key words: Ginsenosides, embryotoxicity, dysmorphogenesis, mesoderm

\section{INTRODUCTION}

The antiquity of herbal medicine practice is perhaps as deep-rooted as the civilization itself. With the institution of allopathy, 'Herbalism' went into a swift decline, however, free accessibility and self-proclaimed benefits make them the first line of treatment in a number of developing and developed countries. Ginseng is one of the most frequently consumed and exceedingly investigated herbs ${ }^{1,2}$. Chemically active fundamentals entitled Ginsenosides are dispersed in the plant in variable concentrations and due to maximum concentration the root is treasured ${ }^{3}$. The hypothalamus-pituitaryadrenal axis and immuno-stimulations are the pathways by which the herb yields its effects ${ }^{4,5,6}$. The growing acceptance of these therapies may upsurge the inadvertent use of medicinal herbs particularly in antepartum period, raising the likelihood of antagonistic fetal or neonatal effects $^{7,8}$. Out of the traditional Chinese remedies used in pregnancy Ginseng was used in $31.7 \%$ gestations, the probable indicator for its extensive usage was maternal wellbeing and prevention of intra-uterine growth retardation ${ }^{9}$. Innumerable in vitro experiments have demonstrated undeviating effects of Ginsenoside on embryos ${ }^{10,11,12,13,14}$; unconjugated steroids pass the placental membrane without any hindrance and effect the fetal progression and differentiation ${ }^{15}$. Ashmaoui et al in 2003 demonstrated numerical \& structural chromosomal aberrations associated with Ginseng usage; Ginsenosides had noteworthy teratogenic and morphologic effects on rat embryos especially when the dose concentration was $\geq 30 \mu \mathrm{g} / \mathrm{ml}^{14}$.

\section{MATERIALS AND METHODS}

18 pregnant dams were randomly divided into three groups with two male albino mice in each group; the animals were kept under controlled settings in the animal house of University of Health Sciences, Lahore. The dams in Group A were given $0.1 \mathrm{ml}$ of distilled water; Group B dams received $780 \mathrm{mg} / \mathrm{kg} /$ day of Ginseng root powder (Low dose) and Group C dams were given $1560 \mathrm{mg} / \mathrm{kg} /$ day (high dose) of Ginseng root powder. The root 
powder was given orally to the experimental animals in $0.1 \mathrm{ml}$ of distilled water for 20 days of pregnancy.

\section{Microscopic Examination}

The pups were dissected under the dissecting microscope and the organs (liver, kidneys) were attained. The processed tissues were embedded in paraffin and stained with $\mathrm{H} \& \mathrm{E}$ for light microscopic study.

\section{Blood Cell Count of Liver}

Regions adjacent to the central vein were chosen for the blood cell count in the liver; the blood cells were counted per $\mathrm{mm}^{2}$ at five sites and their mean was taken under X 63 using a 10 x 10 reticule.

\section{Skeletal Staining}

To evaluate the skeletal deformities in the pups the procedure embraced was Alcian Blue - Alizarin Red Skeletal Staining technique16.

\section{Statistical Analysis}

Qualitative data was analyzed using chi square test and quantitative data was analyzed using students't' test.

\section{RESULTS}

Paraxial mesoderm (Skeletal system)

Axial skeleton evaluation demonstrated disproportionate bone element of the sternum and the ribs. Defect in the lumber vertebrae of animals on high dose was also noted. The transverse processes were not united with the vertebral body; however, vertebral spine was normal (Table 1)

Table 1: Skeletal malformations in experimental groups as compared to control group.

\begin{tabular}{|l|l|l|l|l|l|}
\hline $\begin{array}{c}\text { Group (number of } \\
\text { embryos) }\end{array}$ & \multicolumn{1}{|c|}{$\begin{array}{c}\text { Embryos with skeletal } \\
\text { malformations }\end{array}$} & $\begin{array}{c}\text { Embryos with no } \\
\text { skeletal deformities }\end{array}$ & $\begin{array}{c}\text { Degree of } \\
\text { freedom }\end{array}$ & $\mathbf{X}^{\mathbf{2}}$ & $\mathbf{p}^{- \text {Value }}$ \\
\hline A (52) & 00 & 52 & 1 & 16.488 & $<0.05$ \\
\hline B (47) & 05 & 12 & & 20.512 & $<0.05$ \\
\hline C (43) & 04 & 12 & & \\
\hline
\end{tabular}

$\mathrm{P}$ value $<0.05$ was considered statistically significant

\section{Intermediate Mesoderm (kidneys)}

The numbers of glomeruli seen in the experimental groups were markedly reduced as compared to the control group; the reduction in the number was not only statistically significant $p<0.05$ but was also dose dependent.

Table 2: Reduction in Number of renal glomeruli in experimental and control groups

\begin{tabular}{|l|l|l|l|l|}
\hline Group (number of embryos) & \multicolumn{1}{|c|}{ Range per $\mathbf{~ m m}^{\mathbf{2}}$} & \multicolumn{1}{|c|}{ Mean \pm SE } & Value of 't' & \multicolumn{1}{|c|}{$\mathbf{p}$ - Value } \\
\hline A (52) & $3-6$ & $4.17 \pm 0.126$ & 34.785 & $0.000^{*}$ \\
\hline B (47) & $1-6$ & $2.27 \pm 0.16$ & 14.221 & $0.000^{* *}$ \\
\hline C (43) & $1-4$ & $1.8 \pm 0.133$ & 14.035 & $0.000^{* * *}$ \\
\hline
\end{tabular}

The visceral and parietal layers exhibited statistically significant signs of cellular degeneration in the experimental groups $(\mathrm{p}<0.05$ : Table 3$)$.

Table 3: Cellular degeneration/apoptosis seen in visceral and parietal layers of renal glomeruli in experimental and control groups

\begin{tabular}{|l|l|l|l|l|l|}
\hline $\begin{array}{c}\text { Group (number of } \\
\text { embryos) }\end{array}$ & Fetuses with malformations & $\begin{array}{c}\text { Fetuses with no } \\
\text { malformations }\end{array}$ & df & \multicolumn{1}{|c|}{$\mathbf{X}^{\mathbf{2}}$} & p-Value \\
\hline $\mathrm{A}(52)$ & 00 & 52 & 1 & 12.30 & $<0.05^{*}$ \\
\hline $\mathrm{B}(47)$ & 10 & 37 & 1 & 9.87 & $<0.05^{*}$ \\
\hline $\mathrm{C}(43)$ & 20 & 19 & & & \\
\hline
\end{tabular}


The medullary and the cortical collecting ducts demonstrated dose dependent, statistically significant $(\mathrm{p}<$ $0.05)$ degeneration \& cell death (Table 4).

Table 4: Medullary \& cortical collecting duct degeneration \& cell death in experimental and control groups

\begin{tabular}{|l|l|l|l|l|l|}
\hline $\begin{array}{c}\text { Group (number of } \\
\text { embryos) }\end{array}$ & $\begin{array}{c}\text { Fetuses with tubular } \\
\text { degeneration }\end{array}$ & $\begin{array}{c}\text { Fetuses with no } \\
\text { tubular degeneration }\end{array}$ & df & \multicolumn{1}{|c|}{$\mathbf{X}^{2}$} & p- value \\
\hline A (52) & 00 & 52 & 1 & 18.04 & $<0.05^{*}$ \\
\hline B (47) & 14 & 33 & 1 & 9.87 & $<0.05^{* *}$ \\
\hline C (43) & 20 & 19 & & & \\
\hline
\end{tabular}

\section{Angiogenesis}

The mesodermal lineage cells witnessed in histological section of the fetal liver were Neutrophils, Eosinophils, Lymphocytes \& Erythrocytes, the change in the number of cells detected is summarized in Table 5

Table 5: comparison of Mesodermal lineage cells in liver

\begin{tabular}{|c|c|c|c|c|c|c|c|c|}
\hline \multirow[t]{2}{*}{$\begin{array}{c}\text { Group } \\
\text { (number of } \\
\text { embryos) } \\
\end{array}$} & \multicolumn{2}{|c|}{$\begin{array}{c}\text { Neutrophils } \\
\text { (Range) per } \mathbf{m m}^{2}\end{array}$} & \multicolumn{2}{|c|}{$\begin{array}{c}\text { Eosinophils } \\
\text { (Range) per } \mathbf{m m}^{2}\end{array}$} & \multicolumn{2}{|c|}{$\begin{array}{c}\text { Lymphocytes } \\
\text { (Range) per } \mathbf{m m}^{2}\end{array}$} & \multicolumn{2}{|c|}{$\begin{array}{c}\text { Erythrocytes } \\
\text { (Range) per } \mathbf{m m}^{2}\end{array}$} \\
\hline & & Mean \pm SE & & Mean \pm SE & & Mean \pm SE & & Mean \pm SE \\
\hline A (52) & $0-3$ & $1.00 \pm 0.122$ & $0-2$ & $0.49 \pm 0.11$ & $3-15$ & $5.79 \pm 0.39$ & $0-18$ & $3.59 \pm 0.5962$ \\
\hline B (47) & $0-4$ & $1.04 \pm 0.132$ & $0-2$ & $0.77 \pm 0.10$ & $7-17$ & $13.29 \pm 0.39$ & $4-26$ & $17.17 \pm 0.746$ \\
\hline $\mathrm{C}(43)$ & $0-4$ & $2.05 \pm 0.19$ & $0-2$ & $0.82 \pm 0.10$ & $6-25$ & $15.38 \pm 0.79$ & $5-51$ & $21.44 \pm 1.62^{c}$ \\
\hline
\end{tabular}

There was a statistically significant change in the number of blood cells witnessed in the experimental groups in comparison with control group. The most imperative increase was in the Erythrocytes count observed in the experimental groups as compared to control group.

\section{DISCUSSION}

In several nations, herbal medicines such as extracts of Ginseng are employed on the market as supplements, which are easily accessible over the counter without any supportive scientific evidence $^{17}$. The fetuses in the treated groups showed arrested growth and gross malformations; anomalies of the skeletal system and gross structure were remarkably prominent in the group receiving high dose (Table 1). The findings were statistically significant $(\mathrm{p}<0.05)$ and corroborate with the findings of Ashmaoui et $\mathrm{al}^{14}$. Previous experimental studies have shown noteworthy morphological and teratogenic effects in fetuses of mothers treated with herb extract ${ }^{11,12,13,14}$. Chan et al in 2003 conducted an experiment to evaluate the effects of Ginsenoside $\mathrm{Rb} 1$ on a whole rat embryo culture; they established that reduction in somite number \& Crown-Rump Length was pronounced when the concentration of Ginsenosides was Increased ${ }^{11}$; the findings are in harmony with our work, indicating embryotoxicity. Degenerated pale areas in the subcortical region of the renal interstitium with scattered nuclei showed signs of decay; the cells did not exhibit any distinctive cell boundaries; changes seen in the light microscopic pictures were probably the result of apoptosis triggered by Ginseng saponins. Numerous Ginsenosides have demonstrated cytotoxic and delayed differentiation against tumor cells, while a couple of others have shown complete contradictory effects ${ }^{1,18}$. Propagation of the G1 stage of cell cycle is constant feature of ginsenoside $\mathrm{Rh} 2^{19}$. Active components of ginseng bear the same organization as that of steroid hormones, owing to which are able to move across the placental membrane without any hindrance, arresting cell division and 
differentiation. As is the case with the steroids, they can adhere with the nuclear membrane receptors hampering the mRNA transcription leading to defective protein synthesis ${ }^{20}$. The features of cellular disintegration $\&$ death seen in cortical \& medullary collecting ducts possibly resulted on account of elevated NO production triggered by Ginsenosides; a major functional component of Ginseng root is known to elevate levels of $\mathrm{NO}_{2}$ and $\mathrm{NO}_{3}{ }^{21,22}$. Evident in microscopic sections, was an abundance of blood cells in the histological sections of liver. The treated groups manifested an increase in blood cell count with the amount of lymphocytes and erythrocytes more pronounced in the histological preparations); the increase in lymphocyte number, observed in the treated groups, was statistically significant ( $\mathrm{p}<0.05$ : Table 15). The number of the lymphocytes increased with the increasing dose of the Ginsenosides which are known to differentially modulate lymphocyte proliferation $^{23}$; the proliferation of lymphocytes in Ginsenosides treated animals earlier reported is in accord with our findings in which the number of lymphocytes was significantly increased in the treated groups. Migration, proliferation and tube formation of Human umbilical vein endothelial cells (HUVEC) was stimulated by Rg1, which also promoted angiogenesis ${ }^{24,25}$. The escalation in the number of blood cells particularly erythrocytes evident in the liver sections was most probably due to this property of ginseng.

\section{CONCLUSION}

Embryotoxic effects of Ginsenosides in experimental model by implication may be considered to induce some kind of malformations in humans, such as low birth weight. We adjoin with previous researchers in saying that caution should be harvested during usage of over the counter medications including Ginseng products during antenatal period. Results in our experiment propose that auxiliary research and observations during human development and growth are mandatory.

\section{REFERENCES}

1. Attele AS, Wu JA, Yuan CS. Ginseng pharmacology: multiple constituents and multiple actions. Biochemical pharmacology. 1999 Dec 1;58(11):1685-93.

2. Kiefer D, Pantuso T. Panax ginseng. American family physician. 2003 Oct;68(8):1539-42.

3. Thompson CJ, Ernst E. Panax Ginseng: a systematic review of adverse effects and drug interactions. Drug Safety 2002; 25 (5): 323-44.

4. Kitts DD, Hu C. Efficacy and safety of ginseng. Public Health Nutrition 2000; 3(4A): 473-85.

5. Kim DH, Moon YS, Jung JS, Min SK, Son BK, Suh HW, Song DK. Effects of ginseng saponin administered intra peritoneally on the hypothalamopituitary-adrenal axis in mice. Neuroscience letters. 2003 May 29;343(1):62-6.

6. Mahaday GB, Gyllenhaal C, Fong H, Frnsworth NR. Ginseng: a review of safety and efficacy. Nutrition in clinical care 2000; 3(2): 90-101.

7. Coleman CI, Hebert JH, Reddy P. The effects of Panax ginseng on quality of life. Journal of Clinical Pharmacy and Therapeutics 2003; 28: 5-15.

8. Chin RK. Ginseng and common pregnancy disorders. Asia- Oceania Journal of Obstetrics and Gynaecology. 1991 Dec;17(4):379-80.

9. Ong CO, Chan LY, Yung PB, Leung TN. Use of traditional Chinese herbal medicine during pregnancy: a prospective survey. Acta obstetrician gynecologica Scandinavica. 2005 Jan 1;84(7):699700.

10. Liu P, Yin H, Xu Y, Zhang Z, Chen K, Li Y. Effects of ginsenoside $\mathrm{Rg} 1$ on post implantation rat and mouse embryos cultured in vitro. Toxicology in Vitro. 2006 Mar 1;20(2):234-8.

11. Chan LY, Chiu PY, and Lau TK. An in-vitro study of ginsenoside Rb1-induced teratogenicity using a whole rat embryo culture model. Hum Reprod.2003; 18(10): 2166-8.

12. Chan LY, Chiu PY, Lau TK. Embryo toxicity study of ginsenoside $\mathrm{Rc}$ and $\mathrm{Re}$ in in-vitro rat whole embryo culture. Reproductive Toxicology 2004; 19(1): 131-4.

13. Liu $\mathrm{P}, \mathrm{Xu} \mathrm{Y}$, Yin $\mathrm{H}$, Wang J, Chen $\mathrm{K}$, Li Y. Developmental toxicity research of ginsenoside $\mathrm{Rb} 1$ using a whole mouse embryo culture model; Birth Defects Res B DevReprod Toxicol.2005 Apr; 74(2): 207-9.

14. Ashmaoui HME, Girgis SM, Raouf AE. Evaluation of the potential mutagenic effects of ginseng on maternally treated post implanted mouse fetuses. The Egyptian Journal of Hospital Medicine 2003; 13:57-65. 
15. Moore KL, Persaud TV, Torchia MG. The developing human E-Book. Elsevier Health Sciences; 2011 Dec 19.

16. ERDOĞAN D, KADIOĞLU D, PEKER T. Visualisation of the fetal skeletal system by double staining with alizarin red and alcian blue. Gazi Medical Journal. 1995;6(2). 55-58

17. Shane-McWhorter L, Geil P. Interactions between complementary therapies or nutrition supplements and conventional medications. Diabetes Spectrum. 2002 Oct 1;15(4):262-6.

18. Haq I. Safety of medicinal plants. Pak J Med Res. 2004;43(4):203-10.

19. Wakabayashi C, Murakami K, Hasegawa H, Murata J, Saiki I. An intestinal bacterial metabolite of ginseng protopanaxadiol saponins has the ability to induce apoptosis in tumor cells. Biochemical and Biophysical research communications. 1998 May 29;246(3):725-30.

20. Wehling M. Specific, nongenomic actions of steroid hormones. Annual review of physiology. 1997 Mar;59(1):365-93.

21. Han SW, Kim H. Ginsenosides stimulate endogenous production of nitric oxide in rat kidney. The international journal of biochemistry \& cell biology. 1996 May 1;28(5):573-80.
22. Wilcox CS, Welch WJ, Murad F, Gross SS, Taylor G, Levi R, Schmidt HH. Nitric oxide synthase in macula densa regulates glomerular capillary pressure. Proceedings of the National Academy of Sciences. 1992 Dec 15;89(24):11993-7.

23. Cho JY, Kim AR, Yoo ES, Baik KU, Park MH. Ginsenosides from Panax ginseng differentially regulate lymphocyte proliferation. Plantamedica. 2002 Jun;68(06):497-500.

24.Joo SS, Won TJ, Kim MS, Lee DI. Hematopoietic effect of ginsenoside $\mathrm{Rg} 3$ in ICR mouse primary cultures and its application to a biological response modifier. Fitoterapia. 2004 Jun 1;75(3-4):337-41.

25. Tai-Ping DF, Stephan Hu. Differential effects of ginsenosides on endothelial cell biology (on line) 2004. Cited on 11 February 2005. Available from : URL:

www.pasteur.fr/applications/euroconf/angio2/17tai.p df-

\section{Corresponding Author:}

Prof. Sarah Khalid

Department of Anatomy, Shalamar Medical and Dental College, Lahore. Email address: sarah.khalid1@gmail.com 